\title{
Four Early Contributors to Neurosurgery in North America
}

\author{
Julian T. Hoff
}

\begin{abstract}
The lives of four physicians of the past are described, focusing on their unique contributions to the early development of neurosurgery in the United States and Canada. Each influenced the others during these formative years, and each played a major role in the evolution of a new surgical subspecialty.

RÉSUMÉ: Quatre pionniers de la neurochirurgie en Amérique du Nord. Il s'agit d'une description de la vie de quatre médecins du passé, centrée sur leurs contributions particulières au développement de la neurochirurgie aux États Unis et au Canada. Chacun a influencé les autres pendant ces années du début de cette discipline et chacun a joué un rôle majeur dans l'évolution d'une nouvelle sous-spécialité chirurgicale.
\end{abstract}

Can. J. Neurol. Sci. 2000; 27: 254-259

While much has been written about the lives of the four principals featured in this paper, the part each played in the lives of the other three has been described less well. The intent here is to show how William Osler, Harvey Cushing, Kenneth McKenzie, and Wilder Penfield influenced each other during their formative years and how they contributed to the evolution and maturation of neurosurgery in North America.

These four men crossed paths many times. Their collaborations with and stimulation of each other were largely responsible for establishing neurosurgery as a distinct surgical subspecialty. The following vignettes illustrate how this happened.

\section{William OsLer}

William Osler (Figure 1) was born in 1849 in Bond Head, Ontario, a hamlet near Toronto. ${ }^{1,2} \mathrm{He}$ was the son of a clergyman. Young Osler attended the Toronto School of Medicine initially, then transferred to McGill University where he was awarded an M.D. in 1872. As was the custom in those days, he traveled to Europe for a year afterwards, intending to be an ophthalmologist. He returned to Canada without a job. A month later, he was asked to join the faculty at McGill as a lecturer in Medicine and Pathology. For the next ten years, he did over a thousand autopsies and at the same time, became an outstanding clinician and bedside preceptor for students. Osler rose quickly through the academic ranks to full Professor. He developed a significant interest in the nervous system during those formative years, illustrated by a composite of cerebral aneurysms he reported in 1886 from cases studied at the autopsy table ${ }^{3,4}$ (Figure 2).

Dr. Osler was recruited to the University of Pennsylvania in 1884 by Weir Mitchell, the legendary neurologist. ${ }^{5}$ During his four years in Philadelphia, his appreciation of surgery expanded more through an association with W.W. Keen, the noted Professor of Surgery at Jefferson Medical College. ${ }^{6}$

When the new Johns Hopkins Hospital opened in Baltimore in 1889, Osler was recruited to join Halsted, Kelly, and Welch, rounding out the famous four who left an indelible mark on Hopkins and on medicine at the turn of the century. During his days at Hopkins, he wrote "Principles and Practice of Medicine", the most widely quoted medical textbook of the time. ${ }^{7} \mathrm{He}$ published eight editions thereafter, one every three years. Osler revolutionized medical education during those years, bringing it "out of the classroom and onto the wards" where bedside teaching became his trademark. ${ }^{5,8}$ Dr. Osler encountered Harvey Cushing when Cushing was a surgical resident at Hopkins, more during the last two years of his training with William Halsted. 5,9,10 Cushing's growing interest in surgery for brain tumors was discouraged by Halsted, his primary mentor, because he saw little future in that direction. On the other hand, Osler strongly encouraged Cushing to pursue his interest in surgery of the nervous system. In fact, Cushing and Osler became close friends over the next two decades - frequently traveling together and working side by side. ${ }^{11}$ Cushing returned from a productive year in Europe at the turn of the century with a decision to confine his surgery to the nervous system. His strongest supporter was Osler, while Halsted reluctantly allowed him to pursue that direction in his career. ${ }^{5}$ In fact, many patients that

From the Section of Neurosurgery, University of Michigan Health Systems, Ann Arbor, Michigan, USA.

ReCeived February 14, 2000. AcCePted in Final form May 11, 2000. Reprint requests to: Julian T. Hoff, Section of Neurosurgery, University of Michigan Health Systems, 1500 E. Medical Center Drive, Ann Arbor, Michigan 48109-0338 USA. 


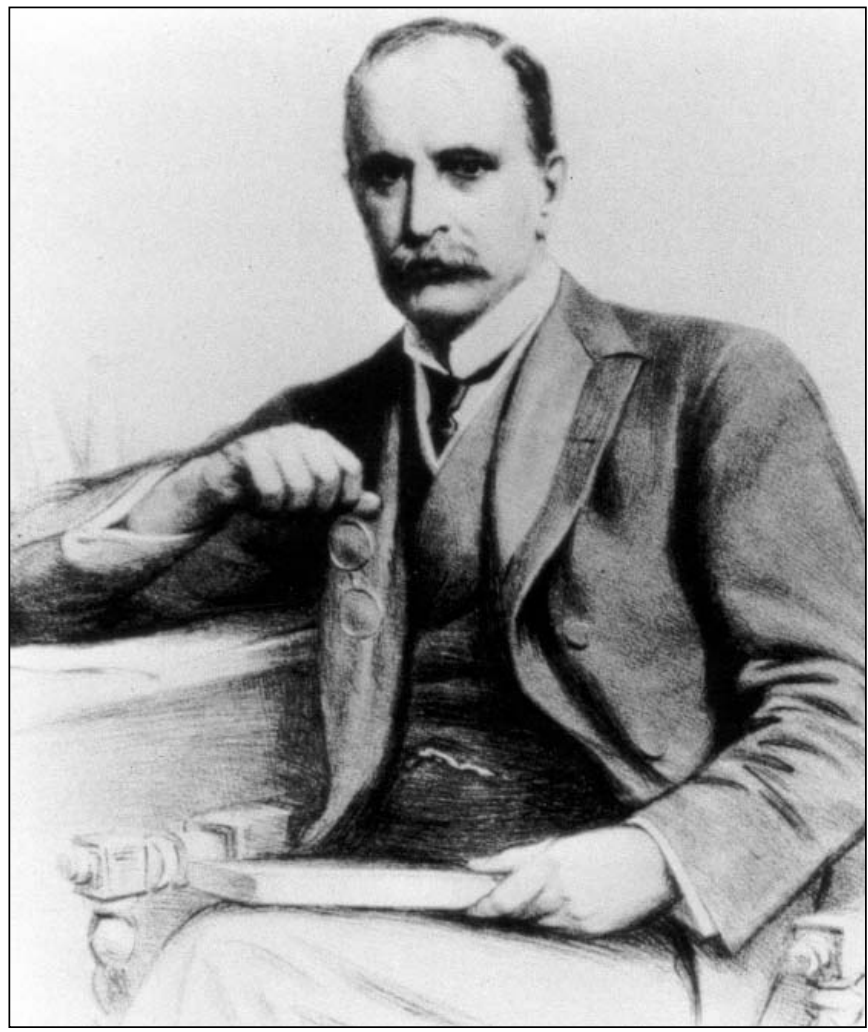

Figure 1: Lithograph of Sir William Osler by George B. Black, about $1911^{2}$

Cushing treated during those early days were referred to him by Dr. Osler. In 1905, William Osler was recruited away to become Regius Professor of Medicine at Oxford. During his years there, his influence on medicine and education continued to grow. He was a prolific writer, historian, bibliophile, and humanitarian. $\mathrm{He}$ was knighted in 1911. Sir William died eight years later at the age of 70. His legacy has continued. An Osler library, based on his own priceless collection of rare medical texts, was established at McGill in 1929 and an Osler Society, of which there are many chapters around the world, evolved. ${ }^{2,11}$ Interestingly, the first honorary member of the American Osler Society was Wilder Penfield, M.D. ${ }^{12}$

\section{Harvey Cushing}

Harvey Cushing (Figure 3) was born in 1869 in Cleveland, Ohio. ${ }^{9}$ He attended Yale University (B.A. 1891), then Harvard Medical School, graduating in 1895. During his final year in medical school, he designed and put to use at the Massachusetts General Hospital what has come to be the anesthetic record used during surgery in all hospitals. After graduation, Cushing went to Johns Hopkins for training in general surgery, and there met Professor Osler. After completing his training in surgery with Halsted, Cushing nearly joined the faculty as a general surgeon at Western Reserve University in Cleveland (later to become Case Western University). ${ }^{9}$ Because of Osler's influence, he traveled to Europe for a year instead, where he encountered Charles Sherrington, Victor Horsley, Hugo Kronecker, Theodor

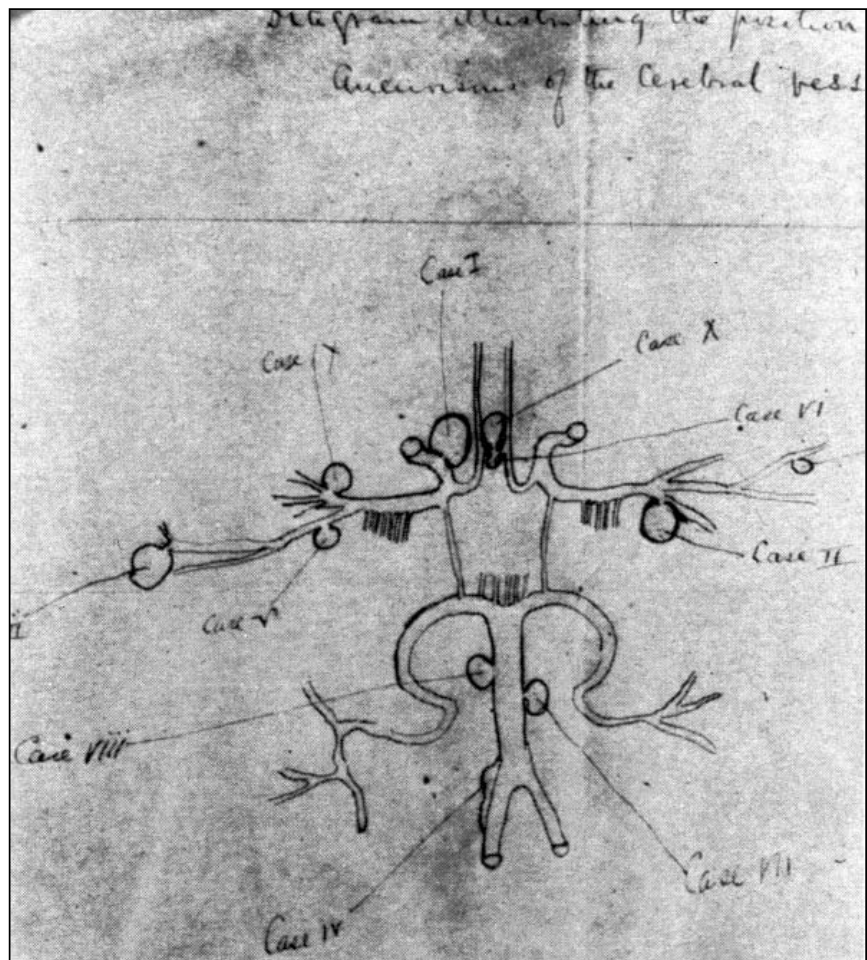

Figure 2: Osler's composite sketch of cerebral artery aneurysms ${ }^{4}$

Kocher, and others. His famous intracranial pressure experiments, which defined the Cushing reflex, took place then. He returned to Baltimore and Johns Hopkins the following year where he remained for the next ten. His practice of neurosurgery expanded from the first year when he treated only two brain tumors, to the final year (1912) by which time he had performed over 250 operations for intracranial neoplasms. Halsted offered reluctant support for his endeavors. Predictably, Osler was a true advocate, having seen neurosurgery done by Horsley in Great Britain during his travels there. ${ }^{13}$ By 1905, Cushing wrote a pivotal article which defined the special field of neurosurgery and he continued to grow professionally. ${ }^{14}$ Cushing's great advantage at Johns Hopkins was that Osler was the principal physician and neurologist. The bond between them became even stronger. During those productive years, Cushing wrote the chapter on "Diseases of the Nervous System" for the sixth edition of Osler's textbook, as well as a chapter on "Surgery of the Head" for W.W. Keen's textbook "The Practice of Surgery" in $1908 .^{15,16}$

In 1912, Dr. Cushing moved to the new Peter-Bent-Brigham Hospital in Boston. When World War I broke out in 1914, he established the Harvard Surgical Unit that served in northern Europe for the duration of that conflict. ${ }^{9}$ Ironically, Osler's son Revere was wounded in action in France and died there in 1917, with Cushing at his bedside. ${ }^{1,5}$

A monumental effort of writing was undertaken by Cushing when Osler died in 1919. His two-volume book on The Life of 


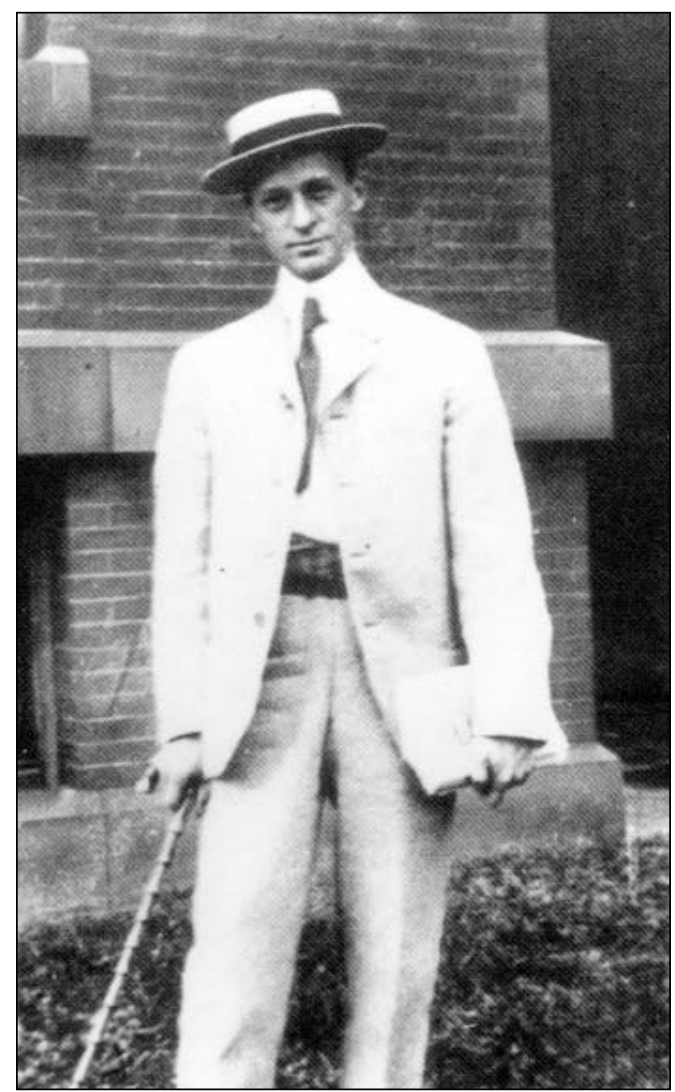

Figure 3: Harvey Cushing, about 1900, from the Alan Mason Chesney Medical Archives. The Johns Hopkins Medical Institution ${ }^{9}$

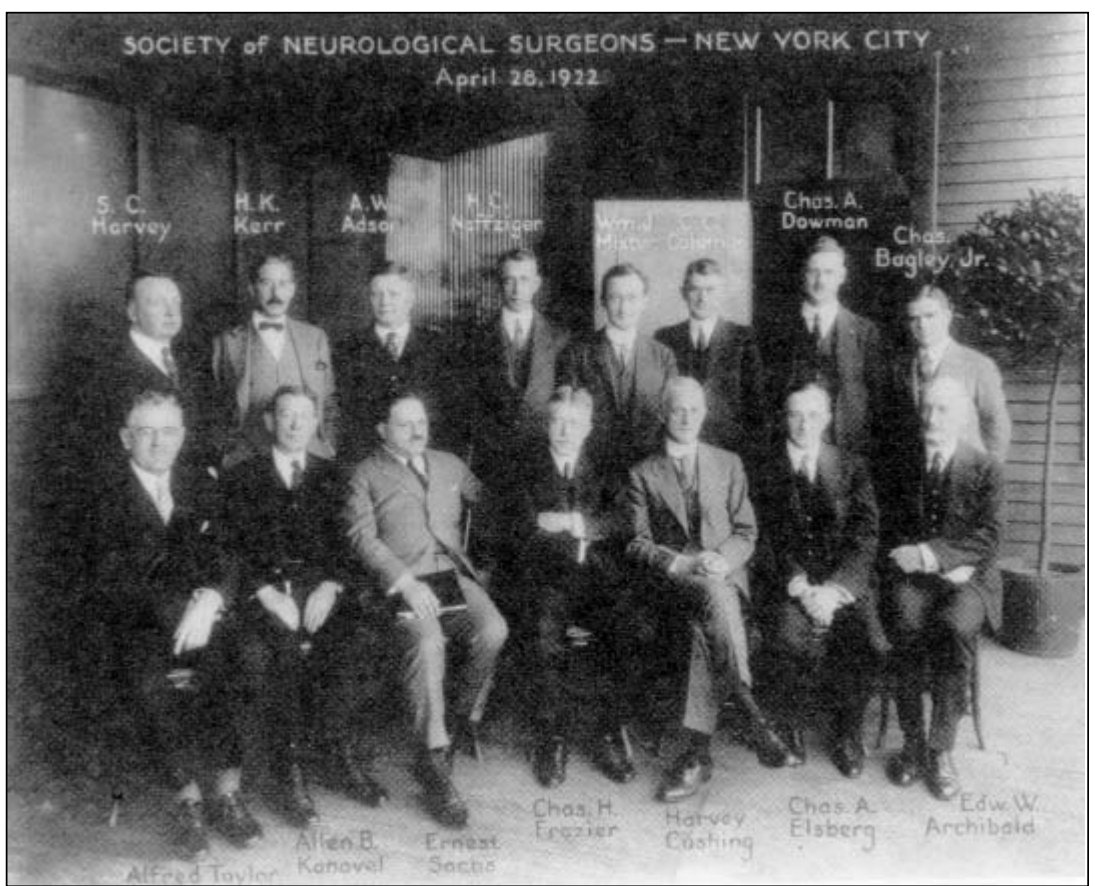

Figure 4: The Society of Neurological Surgeons, 1922. Note Cushing, Sachs, Elsberg, and Archibald in the front row. From The Society of Neurological Surgeons 75th Anniversary Volume. Alexander E II, ed. Jostens Graphics, Winston-Salem, NC, 1995, p 12
Sir William Osler took four years to write. ${ }^{5,9}$ Cushing won the Pulitzer Prize for it in 1925. During the same time, he published many papers, saw many patients, and operated every day. His routine then was three hours with the book every morning, an hour or so with new patients, then the afternoon operating. Rounds followed. He and Ernest Sachs were instrumental in establishing the first neurosurgical society in 1920, initially called the Neurosurgical Club, later the more dignified Society of Neurological Surgeons ${ }^{17}$ (Figure 4). Cushing retired in 1933 because of the mandatory faculty rules in effect at Harvard. He returned to his alma mater in New Haven, where he became Professor of Neurology and set about cataloging his years of experience with the help of Louise Eisenhardt. Together they established the famous Cushing Library. He died in 1939. Cushing's contributions are well-known to all interested in the history of medicine. In essence, he established neurosurgery as a bona fide entity and created the "Cushing School" which fostered future leaders of neurosurgery throughout the world. ${ }^{18,19}$ His artistry and his science left an indelible mark on medicine and surgery.

\section{Kenneth MCKenZIE}

Kenneth McKenzie (Figure 5) was born in 1892 in Monkton, Ontario. ${ }^{20}$ His father was a physician who practiced for 65 years. Young McKenzie attended the University of Toronto, where he won his M.D. in 1914, then volunteered immediately to serve with the British Royal Army Medical Corps at the onset of World War I. ${ }^{21} \mathrm{He}$ served in Europe as a medical officer for both British and Canadian forces from 1914 to 1919 . After returning from the War, he entered general practice in Toronto, even though he wanted to be a surgeon. McKenzie practiced for three years. In 1921, he contacted Professor Clarence Starr, the newly-recruited Chief of Surgery at the Toronto General Hospital. When Cushing gave the Balfour Lecture in 1922 to the Toronto medical community, he was awarded a William Mickel Fellowship consisting of $\$ 1000$. Cushing graciously assigned the honorarium for the Mickel lecture to the University of Toronto for a training fellowship in surgery. ${ }^{9}$ Starr nominated McKenzie as the recipient. Apparently there was little competition for the Fellowship since neurosurgery was not an attractive career in those days.

McKenzie spent a year with Cushing at the Peter-BentBrigham Hospital in Boston. Those were stressful days for him. By Cushing's rules, his family was not allowed to be with him, even though money provided by the Fellowship was given to McKenzie's wife and their three children. McKenzie wrote of that year: "The first few weeks as a resident were difficult, to say the least. ${ }^{15}$ I had never seen a patient suffering from a brain tumor. There were 25 to 30 on the wards at the Brigham at that time. The first problem was to master an ophthalmoscope. I learned to recognize a normal and pathological optic nerve head. 


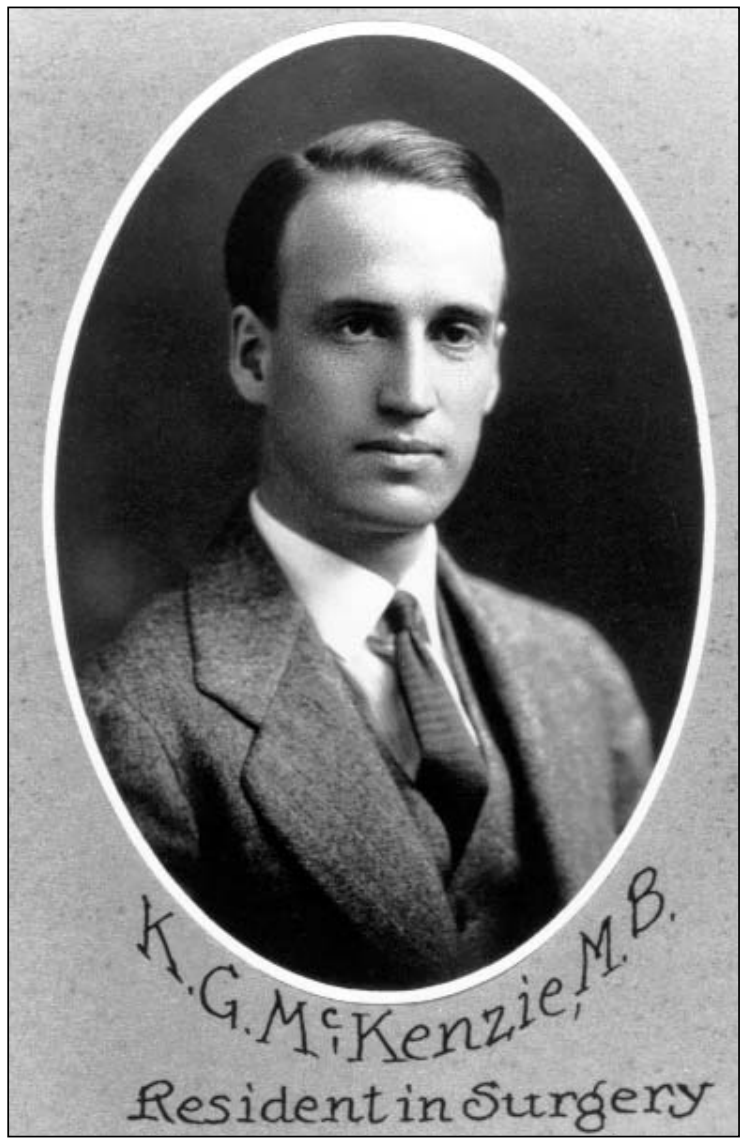

Figure 5: Kenneth McKenzie, 1923-1924. Photograph generously provided by Alan Hudson, M.D., President, Toronto General Hospital

This took some weeks. At the same time, a simple but complete neurological examination had to be applied. This included taking the visual fields with a perimeter. Examination of the patient took hours in the first weeks; later on I learned to do it in minutes. Looking back on my year with Cushing, I recall a man who must have been an extraordinary master of his time. His day's routine seemed to be set weeks ahead and seldom did anything interfere with his plans." 18 To further quote McKenzie: "On his (Cushing's) service, a resident never got very far with a case before it was taken out of his hands and a three or four-hour operation, such as a Vth nerve section, was finished by the Chief. Yet I knew this operation would be one of my first responsibilities when returning to Toronto. Fortunately, before coming home, a visit to Dr. Adson at the Mayo Clinic proved most helpful. He (Adson) had been through the fire and took me under his wing. For the first time, I could see what was being done and felt that his particular technique could be duplicated. The underlying principle, of course, was the sitting up position of the patient so that the blood ran out of the field and did not continually obstruct the surgeon's vision. With a kitchen chair and an attached dental headrest, I became reasonably adept at this procedure and can recall one such operation going rather well when Professor Archibald was looking on."18 (Edward
Archibald, M.D., was Professor of Surgery at McGill then). McKenzie mentions "I have the feeling that it was then that he (Archibald) decided that Montreal should have a neurosurgeon and so Canada acquired Dr. Wilder Penfield."18 In fact, McKenzie and Penfield first met during the year McKenzie trained in Boston (1922-23), and Penfield visited Cushing for the first time that same year. ${ }^{9}$

When McKenzie returned to Toronto in the summer of 1923, Professor Starr asked him to set up a neurosurgery service, recognizing that the specialty was here to stay (Hudson AR. Personal communication. July 22, 1997). His first case was a spinal cord tumor diagnosed clinically without any imaging. For the next several years, he worked alone developing a team, a service, an operating room, and a referral base. He was able to make do with simple things. He became, by consensus of those who worked with him, the most dexterous of brain surgeons. As Professor Thomas Morley described him: he "was a magician with economy of movement, sure of the next step, unfaltering and unflappable."(Personal communication. August 2, 1997.) McKenzie took on his first resident in 1930. William Keith, M.D. was the first of nine. All were eminently successful and all contributed to the establishment of North American neurosurgery. ${ }^{20,21}$

McKenzie firmly believed that neurosurgery belonged in a general hospital where collaboration was easy and competition was encouraged among the surgical subspecialties. ${ }^{22}$ Early on, he recruited a neuropathologist. Later he established neuroradiology at the hospital, well before similar diagnostic units were developed around the world. His contributions were many, particularly in clinical neurosurgery. He was a well-known acoustic surgeon, treated Meniere's disease by vestibular nerve transection sparing the facial nerve and hearing, managed torticollis by multiple rhizotomies, did one of the first hemispherectomies for epilepsy, invented instruments including skull tongs for skeletal traction based on the design of ice tongs, and fashioned cranial burrs from steel drills bought in a hardware store. $^{23,24}$ Above all, he was an educator of his residents. They spread his style across Canada and established his ongoing legacy. All of them harken back to his unparalleled devotion to their education and recall how he allowed them to learn through his direct, hands-on style. ${ }^{20,21,25}$

\section{Wilder Penfield}

Wilder Penfield (Figure 6) was born in Spokane, Washington in $1891 .{ }^{12} \mathrm{He}$ attended Princeton University where he played football, then coached for a year after graduation. On a Rhodes scholarship, he then spent eighteen months at Oxford where Charles Sherrington stimulated his interest in the nervous system. He also met the Regius Professor of Medicine, Sir William Osler, who became a lifelong hero and role model. He returned to begin medical school at Hopkins, graduating in 1918. He became profoundly influenced by Halsted, Professor of Surgery at the time, and two of his most talented surgical residents, Walter Dandy and George Heuer. Both became neurosurgeons later. After Penfield finished medical school, he interned at the Peter-Bent-Brigham Hospital where he first encountered Cushing. Following his internship, he traveled to England to study in the laboratories of Sherrington, at the bedside with Gordon Holmes at Queen Square, and in the 


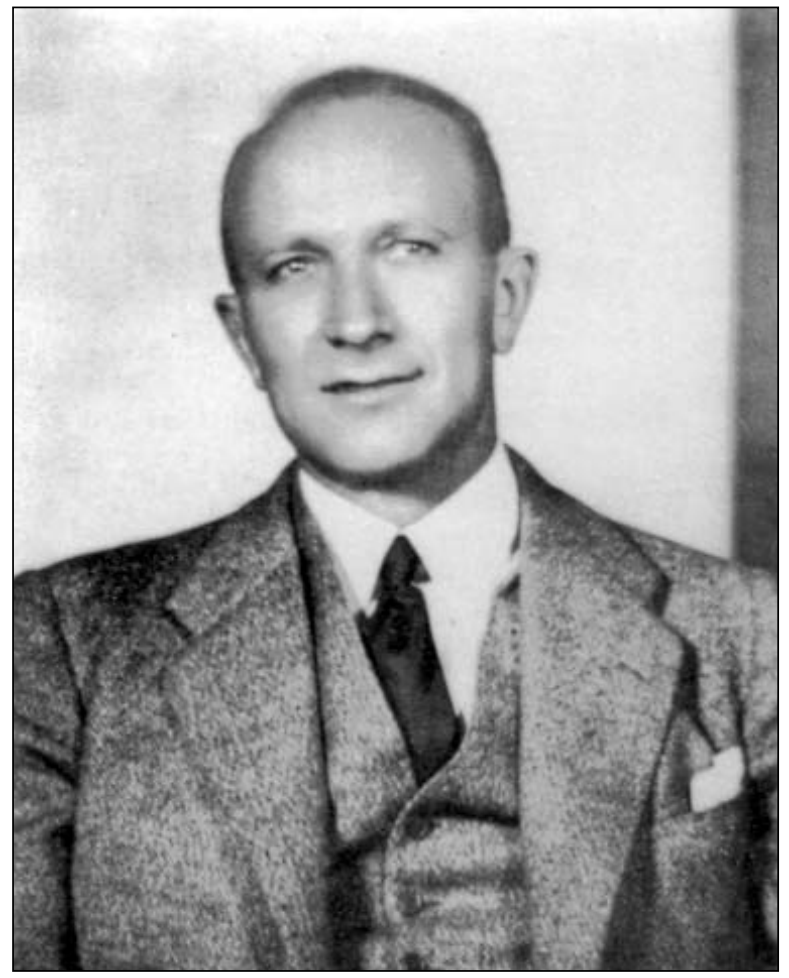

Figure 6: Wilder Penfield, about $1924^{31}$
Neurological Institute (MNI) was founded. ${ }^{12}$ The MNI was based upon Penfield's idea that the clinical and basic neurosciences should be housed in a single unit, separate from, but near a major general hospital where patient care and research advances could be optimized. The next 26 years of his career were marked by the recruitment of outstanding colleagues, the establishment of a famous training program, and maturation of his institute concept. He had the good fortune to work closely with Herbert Jasper, the neurophysiologist and with Theodore Rasmussen and William Feindel, both future Directors of the MNI. One of Penfield's many contributions was mapping the motor, sensory, speech and memory functions of the brain. ${ }^{30}$ The homunculus was his work, with the help of his trainees Edwin Boldrey and Theodore Rasmussen (Figure 7). He also established surgery as an effective treatment for epilepsy, and championed the Institute concept to all four corners of the world.

Penfield's approach to organization of a neuroscience unit was different from that of McKenzie who favored growth of neurosurgery within a general hospital. Penfield believed that neurology and neurosurgery should "combine, a fact that is already theoretically obvious, as neurosurgery is blind without neurology and can hope to make no advance, and neurology is ineffective without surgery." ${ }^{26}$ Reflections on his career were described in his autobiography, No Man Alone, published in 1977, shortly after he died. ${ }^{31}$ David Shephard, editor of the Canadian Medical Association Journal, said of Penfield at the time of his death: "Penfield was a skillful and erudite neurosurgeon, but he was also a visionary, philosopher, educator, and author." 35

Four men who contributed to the early development of

operating theater with Percy Sargent, a student of Horsely. When Penfield returned from abroad, Allen Whipple, Professor of Surgery at Columbia in New York City, offered him a position in surgery. To quote Penfield, "When Whipple sent for me to come to New York for an interview, I confessed to him my shortcomings as a surgeon. He smiled, 'I know,' he said, 'but you have the training I want in neurophysiology and neuropathology and neurology. We can teach you surgery here, and I shall expect you to make recurring visits to the clinics of other neurosurgeons." ${ }^{26}$ It should be recalled that Charles Elsberg was the principal neurosurgeon at the New York Neurological Institute at that time. ${ }^{27}$ It was at the Presbyterian Hospital that Penfield and William Cone first met. They became fast friends and remained lifelong colleagues. Over the next seven years in New York, Penfield traveled to other centers where neurosurgery was better developed. He visited Harvey Cushing on four occasions during his Columbia years and became one of Cushing's "senior pupils." ${ }_{5,28} \mathrm{He}$ also spent six months during 1928 in Germany with Professor Otfrid Foerster, the neurologist and a self-taught neurosurgeon. That same year, 1928, Professor Archibald, Chief of Surgery at McGill, decided it was time to recruit someone to do full time neurosurgery. Archibald had been doing neurosurgery in Montreal even before McKenzie returned to Toronto but had not exclusively confined himself to the specialty. Penfield and Cone were recruited together. ${ }^{29}$ In three years, a Department of Neurology and Neurosurgery had been established and by 1934, with the help of the Rockefeller Foundation and Canadian benefactors, the Montreal

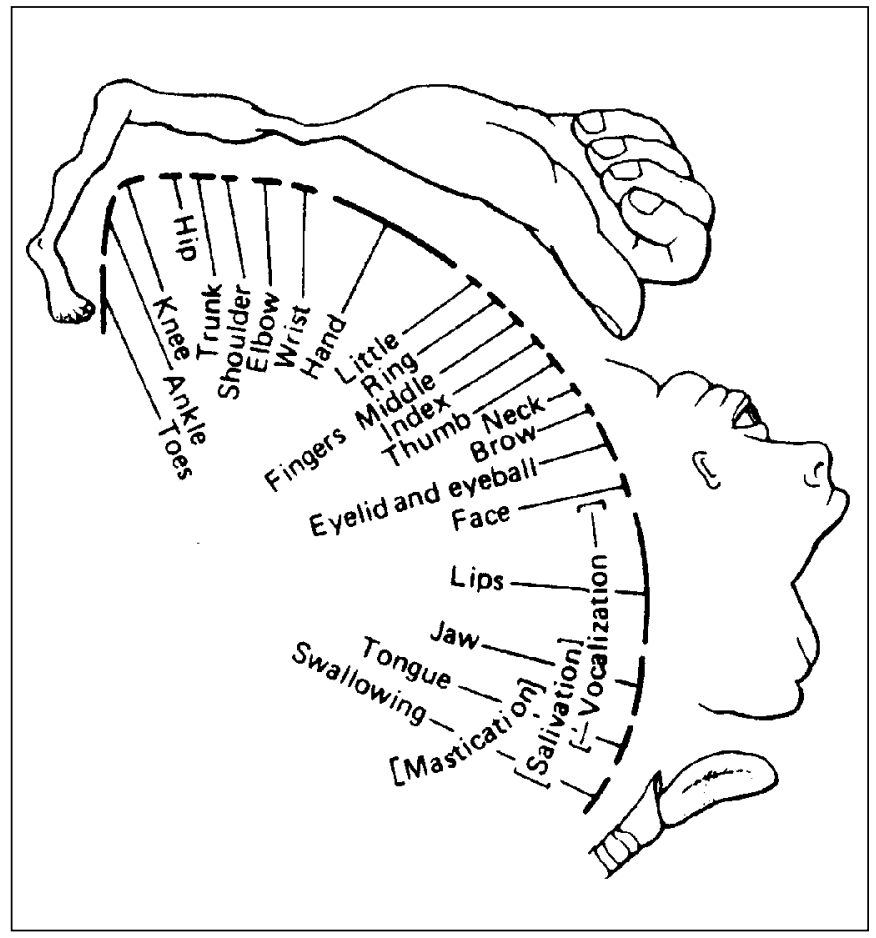

Figure 7: The human motor homunculus ${ }^{33}$ 
neurosurgery in Canada and the United States have been briefly described. There were, of course, others in the early days who played major parts that have not been mentioned. It is clear that William Osler was enormously influential, particularly on the young Harvey Cushing, persuading him to pursue his budding interest in the neurosciences rather than a secure future in general surgery favored by his surgical mentor, William Halsted. Osler also touched Penfield at a critical time in his early professional life, strengthening his commitment to a life of innovation and investigation. Cushing was an important role model for both McKenzie and Penfield. McKenzie spent a tough year in Boston as one of Harvey Cushing's "Boys" where he forged the disciplined approach to his life as a pioneer neurosurgeon that came to be his trademark. He was a champion of his own "Boys" and trained the best. Penfield was similarly indebted to Cushing, treasuring an association that lasted for many years. Though not officially trained by Harvey Cushing, he was recognized by Cushing as "one of his own." Each of them played a unique role in the lives of the other three and made substantial contributions to the development of neurosurgery in North America.

\section{ACKNOWLEDGEMENTS}

This paper was presented as the Presidential Address to a Joint Meeting of The American Academy of Neurological Surgery and the Canadian Neurosurgical Society, September 12, 1997 in Banff, Alberta, Canada.

The author thanks many colleagues who provided material for this paper, particularly Thomas Morley, Max Findlay, Eben Alexander Jr, Alan Hudson, Bryce Weir, William Feindel, Ross Fleming, Charles Tator, and the late Charles Drake. Dr. Feindel graciously critiqued the manuscript. Finally, the author thanks Sandra Yassay for her help with this and other manuscripts over many years.

\section{REFERENCES}

1. Bliss M. William Osler: A Life in Medicine. Toronto: University of Toronto Press, 1999:580.

2. Barondess JA, McGorem JP, Roland CG, eds. The Persisting Osler. University Park Press, 1985.

3. Feindel W. Highlights of Neurosurgery in Canada. JAMA 1967;200:853-859.

4. Osler W. Aneurysms of the larger central arteries. Can Med Surg J 1886; 14:660-666.

5. Cushing H. The Life of Sir William Osler. Oxford: Clarendon, $1925 ; 728$.

6. Erikson GE. Sir William Osler and William Williams Keen. Osler Library Newsletter, Vol II, 1972.

7. Osler W. The Principles and Practice of Medicine. New York: D. Appleton 1892:530.

8. Osler $\mathrm{W}$. The need of a radical reform in our methods of teaching senior students. New York: Med News 1903;82:49-53
9. Fulton JF. Harvey Cushing. A biography. Springfield, IL: Charles C Thomas, 1946.

10. Cushing H. William Stewart Halsted, 1852-1922. Science 1922;56: 461-464.

11. Barondess JA. Cushing and Osler: The evolution of a friendship. Trans and Studies of the College of Physicians of Philadelphia 1985;7:79-104.

12. Feindel W. The Montreal Neurological Institute. J Neurosurg 1991; 75:821-822.

13. Canale DJ. William Osler and "the special field of neurological surgery". J Neurosurg 1989;70:759-766.

14. Cushing H. The special field of neurological surgery. Bull Johns Hopkins Hospital 1905; 16: 77-87.

15. Cushing H. Surgery of the head. In: Keen WW, ed. Surgery, Its Principles and Practice. Philadelphia: WB Saunders, 1908;3:17276.

16. Cushing H. Diseases of the nervous system. In Osler W, ed. The Principles and Practice of Medicine, 6th Ed. New York/London: Appleton, 1905:867-1110.

17. Sachs E. The most important steps in the development of neurological surgery. Yale J Biol Med 1955;28:444-450.

18. McKenzie KG. In memoriam: Harvey Cushing. 1869-1939. Am J Psych 1940;96:1001-1007.

19. Penfield W. The passing of Harvey Cushing. Yale J Biol Med 1940; 12:323-326.

20. Alexander E Jr. Kenneth George McKenzie, Canada's first neurosurgeon. J Neurosurg 1974;41:1-9.

21. Botterell EH. Kenneth George McKenzie, M.D., F.R.C.S., 19231963. Surg Neurol 1982;17:81-89.

22. Findlay JM. Neurosurgery at the Toronto General Hospital 19241990; Part I. Can J Neurol Sci 1994;21:146-158.

23. McKenzie RG. A perforator and ball burr. J Neurosurg 1944;1:5859.

24. McKenzie RG. Intracranial division of the vestibular portion of auditory nerve for Meniere's disease. Can Med Assoc J 1936;34:369-381.

25. Thompson JM. Kenneth George McKenzie. In: History of the Congress of Neurological Surgeons. Baltimore: Williams and Wilkins, 1992.

26. Feindel W, ed., Wilder Penfield. His Legacy to Neurology (18911976). Papers given at a Memorial Meeting, Montreal Neurological Institute, October 29, 1976. Can Med Assoc J 1977;116:3-16.

27. Elsberg CA. The development of neurological surgery in New York during the past twenty-five years. J Mt Sinai Hosp NY 1942;9:413-418.

28. Preul MC, Feindel W. Origins of Wilder Penfield's surgical technique. J Neurosurg 1991; 75: 812-820.

29. Penfield W. Edward Archibald 1872-1945. Can J Surg 1958; 1: 167174.

30. Penfield W, Rasmussen T. The Cerebral Cortex of Man: A Clinical Study of Localization of Function. New York: MacMillan, 1950

31. Penfield W. No Man Alone: A Neurosurgeon's Life. Boston: Little, Brown \& Co., 1977.

32. Shephard DAE. Editorial. The vision of Wilder Penfield. Can Med Assoc J 1977;116:15-16. 